\title{
Controlling dietary cation-anion differences in forages by chloride fertilisation
}

\author{
Lars Nesheim ${ }^{1}$, Olav Martin Synnes ${ }^{2}$, Arvid Steen ${ }^{3}$, Anne Langerud ${ }^{1}$ and Anne Kjersti Bakken ${ }^{1}$ \\ Norwegian Institute of Bioeconomy Research (NIBIO), Division of Food Production and Society, \\ P.O. Box 115, NO-1431 Ås, Norway \\ ${ }^{2}$ Norwegian Agricultural Extension Service Vest, P.O. Box 1312, NO-6001 Ålesund, Norway \\ ${ }^{3}$ Nord $\varnothing$ yane Veterinary Office, NO-6290 Harams $\varnothing y$, Norway \\ anne.kjersti.bakken@nibio.no
}

\begin{abstract}
Rations with low to negative dietary cation-anion difference (DCAD) given to dairy cows before calving reduce the risk of hypocalcaemia (milk fever). Different strategies for increasing forage DCAD were investigated in field trials in Central and Western Norway. Fertilisation with 70,140 or $210 \mathrm{~kg} \mathrm{Cl}$ per hectare as calcium chloride and low supply rates of $\mathrm{K}$ reduced DCAD in forage harvested at late developmental stages in spring growth of timothy and meadow fescue. The ideal negative DCAD was only attained on soils very low in plant available $\mathrm{K}$. Timing (spring versus late spring) and source of $\mathrm{Cl}\left(\mathrm{CaCl}_{2}\right.$ versus $\left.\mathrm{MgCl}_{2}\right)$ were of no importance for the result. When pure stands of seven grasses were fertilised in spring either without chloride or with $140 \mathrm{~kg}$ chloride per hectare, the lowest values of DCAD after chloride fertilisation were found in perennial ryegrass and reed canary grass. By comparison, cocksfoot had equally high or higher $\mathrm{Cl}$ concentrations in its tissues, but accumulated more $\mathrm{K}$, and seemed to be poorly suited for low DCAD forage production. It was concluded that $\mathrm{Cl}$ fertilisation is a more efficient means of controlling DCAD than sward species composition.
\end{abstract}

Key words: calcium chloride, DCAD, grass species, K-fertilisation, magnesium chloride

\section{Introduction}

Hypocalcaemia (milk fever) is a common metabolic disease in dairy herds in the Nordic countries. Its incidence rate in 2017 was $0.049,0.032,0.065$ and 0.088 treatments per cow-year (excluding first parities) in Finland, Sweden, Norway and Denmark, respectively (Nordiska Mejeriorganisationers Samarbetsorgan för Mjölkkvalitetsfrågor 2018, communicated by Olav Østerås).

In the sixties, Ender et al. (1971) showed that using extra supplement of anions in the feed could reduce the risk of milk fever. Feeding rations with low values of dietary cation-anion difference (DCAD) before calving creates a compensated metabolic acidosis in the cows and make the parathormone receptors more sensitive (Goff 2014). The compensated metabolic acidosis makes the urine acid; this acidification hinders calcium reabsorption (Martín-Tereso and Martens 2014). Calcium losses through urine activate the sensitized homeostatic regulation of calcium by increasing bone mobilization and intestinal absorption (Goff 2014, Martín-Tereso and Martens 2014). However, anionic salts are not very palatable and it may thus be difficult to get the cows to eat enough of the products. Forages for dry cows should preferably be of low digestibility and energy concentration, which is presently obtained by harvesting the grass crop at late phenological stages. To further produce this feed with a low DCAD, by Cl fertilisation, would be a cost-effective method to reduce the risk of hypocalcaemia. If feasible, this strategy would have the potential to reduce the challenges related to low palatability and intake of anionic salts.

DCAD is most commonly expressed as the difference between the concentrations of $\mathrm{Na}$ and $\mathrm{K}$ and the concentrations of $\mathrm{Cl}$ and S, expressed in $\mathrm{mEq} \mathrm{kg}^{-1} \mathrm{DM}$ (Ender et al. 1971). The concentrations of $\mathrm{K}$ and $\mathrm{Cl}$ in the forage are easier to manipulate than those of $\mathrm{Na}$ and S (Goff 2014). However, many soil types in the Nordic countries contain rather high levels of plant available $\mathrm{K}$, and grasses tend to take up more $\mathrm{K}$ than is needed for normal growth (Lunnan et al. 2017). Furthermore, cattle slurry rich in $\mathrm{K}$ is often applied at rather high rates throughout the growth period. This is because the number of animals per unit area of farmland is high and the growing season is short. Thus, it may be difficult to produce forage with a low $\mathrm{K}$ concentration on soils where farmers are reluctant to reduce the $\mathrm{K}$ supply because of the risks of yield reductions. 


\section{AGRICULTURAL AND FOOD SCIENCE}

L. Nesheim et al. (2020) 29: 18-28

To prevent milk fever, DCAD in rations fed to non-lactating dairy cows 1-2 weeks before calving should be around $-50 \mathrm{mEq} \mathrm{kg}^{-1} \mathrm{DM}$ (Pelletier et al. 2007). Goff (2014) recommended using forage with a neutral or slightly negative value of DCAD, supplemented with small amounts of anionic salts to achieve a DCAD of -100 to $-150 \mathrm{mEq} \mathrm{kg}^{-1}$ DM. Measurements of urine $\mathrm{pH}$ may be used to decide the supply of ionic salts. The target urine $\mathrm{pH}$ would be 6.5 \pm 0.3 (Goff 2014). The advisory service of the dairy company TINE recommends a DCAD of -150 to 0 in the ration for the 2-3 last weeks before calving (TINE Rådgiving 2014).

Chloride fertilisation has been shown to increase the concentration of $\mathrm{Cl}$ in the forage, and thus reduce its DCAD, even to negative values (Pehrson et al. 1999, Pelletier et al. 2007, Tremblay et al. 2013). Under Canadian conditions, an economically optimal rate of chloride fertiliser applied in spring was between 78 to $123 \mathrm{~kg} \mathrm{Cl} \mathrm{ha}^{-1}$, and $\mathrm{CaCl}_{2}$ and $\mathrm{NH}_{4} \mathrm{Cl}$ appeared to be equally efficient as $\mathrm{Cl}$ sources (Pelletier et al. 2007). To our knowledge, the effect of $\mathrm{MgCl}_{2}$ has not been compared with the effect of other chlorides. Since hypomagnesemia caused by insufficient dietary Mg supply to cows may negatively affect the sensitivity of parathormone receptors (Goff 2014), use of a fertilizer supplying both $\mathrm{Mg}$ and $\mathrm{Cl}$ may give some additional benefit.

In the investigations performed by Pelletier et al. (2008) and Tremblay et al. (2006), the DCAD decreased with advancing stage of grass development, and there were also differences between species in the concentrations of $\mathrm{Na}, \mathrm{K}$ and $\mathrm{Cl}$, and thereby in DCAD. Lowest DCAD was recorded in timothy (Phleum pratense L.) and highest in cocksfoot (Dactylis glomerata L.) and meadow brome grass (Bromus riparius Rehmann). The variation in DCAD in Eastern Canada was mainly related to variation in the uptake/accumulation of $\mathrm{K}$, which was lower in timothy than in the other species (Tremblay et al. 2006).

Hove (1998) analysed mineral concentrations in 100 silage samples from different regions in Norway. The average concentrations of chloride and potassium were $3 \mathrm{~g} \mathrm{~kg}^{-1} \mathrm{DM}$ and $21.3 \mathrm{~g} \mathrm{~kg}^{-1} \mathrm{DM}$, respectively, and the average DCAD was calculated to be $482 \mathrm{mEq} \mathrm{kg}^{-1} \mathrm{DM}$. In an investigation on eight organic and eight conventional dairy farms in Central and Western Norway, Foseide Henriksen (2003) found somewhat lower values for DCAD than did Hove (1998); the average value of DCAD was $366 \mathrm{mEq} \mathrm{kg}^{-1} \mathrm{DM}$ on organic farms and $344 \mathrm{mEq} \mathrm{kg}^{-1} \mathrm{DM}$ on conventional farms. The forage chloride concentration was on average $5.5 \mathrm{~g} \mathrm{~kg}^{-1} \mathrm{DM}$. According to Whitehead (2000), chloride becomes toxic to plants when its concentration approaches $30 \mathrm{~g} \mathrm{~kg}^{-1} \mathrm{DM}$.

In the present study, which was conducted in Central and Western Norway, close to the coast of the North Sea, we have further explored whether DCAD in forages could be controlled by $\mathrm{Cl}$ fertilisation. Various strategies with regard to the rate, source and timing of application were investigated on different soils and with swards of differing species composition. Timing of $\mathrm{Cl}$ application was regarded relevant to investigate due to the risk of leaching of early applied doses under episodes of high precipitation in early spring.

Our hypotheses were: 1) by applying $\mathrm{Cl}$ fertilisers at rates as high as $200 \mathrm{~kg} \mathrm{Cl}$ per ha in spring, herbage with low DCAD values can be produced without yield reduction, 2) $\mathrm{MgCl}_{2}$ is equally as efficient as $\mathrm{CaCl}_{2}$ as $\mathrm{Cl}$ source and contributes to a higher plant concentration of $\mathrm{Mg}, 3$ ) an early or late application of $\mathrm{Cl}$ fertiliser will similarly ensure a high uptake and high tissue concentration of the element at harvest, and 4) $\mathrm{Cl}$ fertilisation is a more efficient means for controlling DCAD in forages than adjusting sward species composition.

\section{Material and methods}

In order to test the above hypotheses, four experiments were included in the present study. Some key information on the different experiments and sites is given in Table 1. The concentrations of readily available potassium (K-AL) and acid-soluble potassium $\left(\mathrm{K}-\mathrm{HNO}_{3}\right.$ ) are given in $\mathrm{mg} \mathrm{K}$ per $\mathrm{kg}$ soil in the $0-20 \mathrm{~cm}$ layer. Values of $\mathrm{K}-\mathrm{AL}$ below $65 \mathrm{mg} \mathrm{kg}^{-1}$ are considered low, values between 66 and 155 are intermediate and those above 155 are considered high. $\mathrm{K}_{-} \mathrm{HNO}_{3}$ values less than $300 \mathrm{mg} \mathrm{kg}^{-1}$ are low, values between 30 and 795 are intermediate and values above 795 are high (Lunnan et al. 2017). 
Table 1. Information on the different experiments and sites. The figures for precipitation are given for the period from spring fertilisation to the first harvest.

\begin{tabular}{|c|c|c|c|c|c|c|c|}
\hline Type of experiment & Site & Years & $\begin{array}{l}\text { Soil- } \\
\text { type }\end{array}$ & $\begin{array}{c}\mathrm{K}-\mathrm{AL} \\
\mathrm{mg} \mathrm{kg}^{-1}\end{array}$ & $\begin{array}{l}\mathrm{K}-\mathrm{HNO}_{3} \\
\mathrm{mg} \mathrm{kg}^{-1}\end{array}$ & $\begin{array}{l}\text { Precipitation } \\
\text { in spring }\end{array}$ & $\begin{array}{l}\text { Weather } \\
\text { station }\end{array}$ \\
\hline \multirow{3}{*}{$\begin{array}{c}\text { Exp. } 1 . \\
\text { Increasing amounts of } \mathrm{Cl}\end{array}$} & Meldal $^{1}$ & 2 & Sandy soil & 80 & 500 & $\begin{array}{l}\text { Year 1: } 162 \mathrm{~mm} \\
\text { Year 2: } 134 \mathrm{~mm}\end{array}$ & Meldal \\
\hline & Stjørdal ${ }^{2}$ & 2 & Clay loam & 110 & 2200 & $\begin{array}{l}\text { Year 1: } 127 \mathrm{~mm} \\
\text { Year 2: } 83 \mathrm{~mm}\end{array}$ & Kvithamar \\
\hline & Haram $^{3}$ & 2 & Sandy soil & 202 & 300 & $\begin{array}{l}\text { Year 1: } 96 \mathrm{~mm} \\
\text { Year 2: } 140 \mathrm{~mm}\end{array}$ & Vigra \\
\hline $\begin{array}{c}\text { Exp. } 2 . \\
\text { Type of Cl fertiliser }\end{array}$ & Vigra $^{4}$ & 2 & Sandy soil & 40 & 250 & $\begin{array}{l}\text { Year 1: } 138 \mathrm{~mm} \\
\text { Year 2: } 126 \mathrm{~mm}\end{array}$ & Vigra \\
\hline \multirow{2}{*}{$\begin{array}{c}\text { Exp. } 3 . \\
\text { Time of appl. of Cl }\end{array}$} & Stjørdal ${ }^{2}$ & 1 & Clay loam & 60 & 1100 & Year 1: $169 \mathrm{~mm}$ & Kvithamar \\
\hline & Vigra $^{5}$ & 1 & Sandy soil & 100 & 300 & Year 1: $195 \mathrm{~mm}$ & Vigra \\
\hline \multirow{2}{*}{$\begin{array}{c}\text { Exp. } 4 . \\
\text { DCAD in grasses }\end{array}$} & Haram $^{3}$ & 2 & Sandy soil & 100 & 400 & $\begin{array}{l}\text { Year 1: } 140 \mathrm{~mm} \\
\text { Year 2: } 134 \mathrm{~mm}\end{array}$ & Vigra \\
\hline & Stjørdal ${ }^{2}$ & 2 & Clay loam & 60 & 1050 & $\begin{array}{l}\text { Year 1: } 136 \mathrm{~mm} \\
\text { Year 2: } 97 \mathrm{~mm}\end{array}$ & Kvithamar \\
\hline
\end{tabular}

${ }^{1} 63^{\circ} \mathrm{O2}^{\prime} \mathrm{N} 9^{\circ} 42^{\prime} \mathrm{E} 135 \mathrm{~m}$ altitude, ${ }^{2} 63^{\circ} 30^{\prime} \mathrm{N} 10^{\circ} 54^{\prime} \mathrm{E} 30 \mathrm{~m}$ altitude, ${ }^{3} 62^{\circ} 39^{\prime} \mathrm{N} 6^{\circ} 14^{\prime} \mathrm{E} 15 \mathrm{~m}$ altitude, ${ }^{4} 62^{\circ} 33^{\prime} \mathrm{N} 06^{\circ} 06^{\prime} \mathrm{E} 20 \mathrm{~m}^{2}$ altitude, ${ }^{5} 62^{\circ} 33^{\prime} \mathrm{N}$ $06^{\circ} 06^{\prime} \mathrm{E} 5 \mathrm{~m}$ altitude

\section{Increasing amounts of calcium chloride fertiliser applied to grassland (Experiment 1)}

A fertiliser experiment was established in 2012 on young leys (first and second year of ley) dominated by timothy and meadow fescue (Festuca pratensis L.) at three sites in Central and Western Norway. Information on soil type, concentrations of potassium and amounts of precipitation in the period from fertilisation to first harvest is given

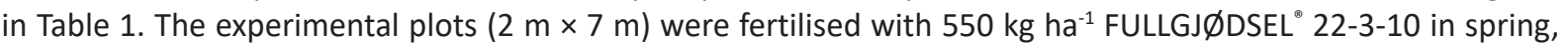
which supplied $119 \mathrm{~kg} \mathrm{~N} \mathrm{ha}^{-1}, 14 \mathrm{~kg} \mathrm{P} \mathrm{ha}^{-1}$ and $53 \mathrm{~kg} \mathrm{~K} \mathrm{ha}^{-1}$. After the first cut, $80 \mathrm{~kg} \mathrm{~N} \mathrm{ha}^{-1}, 11 \mathrm{~kg} \mathrm{P} \mathrm{ha}^{-1}$ and $36 \mathrm{~kg}^{-1}$ $\mathrm{K} \mathrm{h}^{-1}$ were applied as FULLGJ $\varnothing \mathrm{DSEL}^{\bullet}$ 22-3-10. In addition to FULLGJ $\varnothing \mathrm{DSEL}^{\circ}$ 22-3-10, the following amounts of chloride were applied as calcium chloride (TETRA CC farm $77 \%$ calcium chloride) in spring, with three replicates: $0,70,140$ and $210 \mathrm{~kg} \mathrm{ha}^{-1}$. The application of potassium was about one half of the recommended amount, based on analysis of soil samples, in order to avoid excessive K-concentrations in the forage. In one treatment (normal K supply), an additional amount of $55 \mathrm{~kg} \mathrm{~K} \mathrm{ha}^{-1}$ in Kali 49 fertiliser was applied. The latter contains $49.8 \%$ potassium and $45.2 \%$ chloride. This extra potassium fertilisation resulted in an application of $50 \mathrm{~kg} \mathrm{Cl} \mathrm{ha}^{-1}$ on plots with the 'normal K supply' treatment. The application of $550 \mathrm{~kg} \mathrm{ha}^{-1} \mathrm{FULLGJ} \varnothing \mathrm{DSEL}{ }^{\circ} 22-3-10$ provided an additional amount of $48 \mathrm{~kg} \mathrm{ha}^{-1}$ of $\mathrm{Cl}$ on all plots. Chloride was applied in spring in both the first and second year. The experimental plots were harvested in 2012 and 2013. The first cut was taken about two weeks after the start of heading of timothy. This is 1-2 weeks later than normal when harvesting high quality forage for lactating dairy cows. The intention of the delayed harvest was to produce forage of low digestibility appropriate for dry cows. The dietary cation-anion difference (DCAD), in terms of $\mathrm{mEq} \mathrm{kg}^{-1} \mathrm{DM}$, was calculated according to the following equation: $((\mathrm{Na} / 22.9)+(\mathrm{K} / 39.1))-((\mathrm{Cl} / 35.5)+(\mathrm{S} \times 2 / 32.07)) * 1000$, where $\mathrm{Na}, \mathrm{K}, \mathrm{Cl}$ and $\mathrm{S}$ concentrations are in $\mathrm{g} \mathrm{kg}^{-1} \mathrm{DM}$.

\section{Chloride applied to grassland in either calcium or magnesium compounds (Experiment 2)}

A field experiment (plots of $2 \mathrm{~m} \times 7 \mathrm{~m}$, three replicates) was established in a sward dominated by timothy and meadow fescue at one site in Western Norway (Vigra) in 2013. The concentration of $\mathrm{K}_{-} \mathrm{HNO}_{3}$ was $250 \mathrm{mg} \mathrm{kg}^{-1}$. The five treatments were: $0 \mathrm{~kg} \mathrm{Cl}, 140 \mathrm{~kg} \mathrm{Cl} \mathrm{ha}^{-1}$ in either calcium chloride (TETRA CC farm 77\% calcium chloride) or magnesium chloride (MG Kombi $37 \% \mathrm{Cl}$ ) as well as $280 \mathrm{~kg} \mathrm{Cl}$ in calcium chloride. The level of potassium supply on treatments 1-3 was $53 \mathrm{~kg} \mathrm{ha}^{-1}$, or about half of the 'normal' or recommended amount based on analysis of soil samples. In treatment 4 (normal K supply) about $55 \mathrm{~kg} \mathrm{ha}^{-1}$ of potassium and $50 \mathrm{~kg}$ of chloride were applied in Kali 49. Applications of N, P, additional $\mathrm{Cl}$ and the stage of development at harvest were similar to those in Experiment 1 (above). Forage dry matter yields and mineral concentrations were recorded at the first cut in 2014 and 2015. 


\section{Chloride applied at spring fertilisation or two weeks later (Experiment 3)}

Two field trials (plots of $2 \mathrm{~m} \times 7 \mathrm{~m}$, three replicates) were established in 2014 on a second-year ley, dominated by timothy and meadow fescue (Stjørdal, Central Norway), and on a five-year-old grass sward (Vigra, dominated by timothy). In these trials, $140 \mathrm{~kg} \mathrm{Cl} \mathrm{ha}^{-1}$ in calcium chloride (TETRA CC farm 77\% calcium chloride) was applied either at the normal time in spring (start of growth), or approximately two weeks later. At Stjørdal the dates of application were 23 April and 9 May. The corresponding dates at Vigra were 2 May and 15 May. The trials were harvested on 16 June and 17 June, about two weeks after heading of timothy. Nitrogen, phosphorus and potassium were applied in FULLGJ ØDSEL ${ }^{\circ}$ at the normal time in spring. $\mathrm{N}$ and $\mathrm{P}$ were applied at adjusted rates, but the level of $\mathrm{K}$ was about $50 \%$ of the normal level. These experiments were harvested in only one year.

\section{DCAD in different grass species (Experiment 4)}

In a further experiment, pure stands of seven grass species were established at two sites (Haram and Stjørdal) in 2012, and fertilised and harvested in 2013 and 2014. The grass species were: timothy (cv. Grindstad), meadow fescue (cv. Fure), cocksfoot (cv. Frisk), smooth brome grass (cv. Leif), reed canary grass (Phalaris arundinacea L.) (cv. Lara), perennial ryegrass (Lolium perenne L.) (cv. Fia) and festulolium (Festulolium Asch. \& Graebn) (cv. Hykor). The grasses were seeded on small plots $(2 \mathrm{~m} \times 7 \mathrm{~m})$, with two replicates. The seed rates were: timothy $20 \mathrm{~kg} \mathrm{ha}^{-1}$, perennial ryegrass and reed canary grass $25 \mathrm{~kg} \mathrm{ha}^{-1}$, cocksfoot and meadow fescue $30 \mathrm{~kg} \mathrm{ha}^{-1}$, festulolium $35 \mathrm{~kg} \mathrm{ha}^{-1}$ and smooth brome grass $45 \mathrm{~kg} \mathrm{ha}^{-1}$. In both the first and second ley year the plots were fertilised with either zero or $140 \mathrm{~kg} \mathrm{Cl} \mathrm{ha}^{-1}$ in calcium chloride (TETRA CC farm $77 \%$ calcium chloride) in spring on main plots. Recommended rates, based on soil samples and expected production, of $\mathrm{N}$ and $\mathrm{P}$, and $75 \%$ of the recommended rate of $\mathrm{K}$ were applied in FULLGJ ØDSEL ${ }^{\circ}$. The first cut of all species except smooth brome grass and reed canary grass was taken about two weeks after the start of heading of timothy. Smooth brome grass and reed canary grass were harvested one week later, when these species had attained about the same stage of phenological development that timothy and the other species had had a week earlier.

\section{Harvesting and sampling}

All yield recording and plant sampling operations were conducted on areas of ca. $1.5 \mathrm{~m} \times 5.5 \mathrm{~m}$ within plots of greater size that differed between experiments. The mower was a Haldrup plot harvester at Kvithamar and a reciprocating mower at Haram, Vigra and Meldal. The stubble height was $7 \mathrm{~cm}$. Sub-samples of ca. $1 \mathrm{~kg}$ of the weighed fresh yield were randomly sampled by hand from all plots in experiments $1-4$. They were dried at $60{ }^{\circ} \mathrm{C}$ and the dry weights were later recorded for total dry matter yield estimation.

\section{Laboratory analyses}

The samples were dried at $60{ }^{\circ} \mathrm{C}$ for 48 hours, and ground in a Cyclotec mill with a $1.0 \mathrm{~mm}$ sieve, and later analysed for elemental concentration by ICP-OES at Eurofins Agro (www.eurofins.no) using accredited methods. Dried samples from the field trials were analysed for feed quality parameters by NIRS at NIBIO's own laboratory, calibrated according to chemical analyses, in vitro analyses (dry matter digestibility, DMD) and in sacco analyses (indigestible neutral detergent fibre, iNDF) (Fystro and Lunnan 2006). The parameters were crude protein, neutral detergent fibre (NDF), iNDF, water-soluble carbohydrates (WSC) and DMD. Values of energy concentration per kg of feed dry matter (Sundstøl and Ekern 1992) were transformed to net energy of lactation at a 20 kg dry matter intake $\left(\mathrm{NEL}_{20}\right)$ using a factor of 7.075 (TINE 2015).

Soil samples were analysed at Eurofins Agro. Easily releasable K (K-AL), Mg-AL and Ca-AL was estimated by the method of Egner et al. (1960), with which the soil is extracted by an ammonium acetate lactate solution (0.1 M ammonium lactate and $0.4 \mathrm{M}$ acetic acid, $\mathrm{pH} 3.75)$ at a ratio of soil to solution of $1: 20(\mathrm{w} / \mathrm{v})$. Acid-soluble $\mathrm{K}$ was extracted by boiling soil samples in $1 \mathrm{M} \mathrm{HNO}_{3}$ (ratio of soil to solution of 1:10 [w/v]) for $10 \mathrm{~min}$.

\section{Statistical analyses}

Analyses of variance of data for forage yield and mineral composition were derived from linear mixed-effects models using the procedure GLM in SAS (release 9.4, 2002-2012, SAS institute inc., Cary, NC, USA). In the statistical analyses all factors were considered as fixed. 


\section{AGRICULTURAL AND FOOD SCIENCE}

L. Nesheim et al. (2020) 29: 18-28

In experiments 1 and 2 the factor fertilisation had five levels, in experiment 3 three levels and in experiment 4 two levels. The analysis of experiment 4 was according to a split-plot design with fertilisation on main plots and grass species on sub-plots, and for the other three experiments according to a randomized block design with fertiliser treatments randomized within blocks. Means were separated by using the procedure PDIFF in the LSMEAN statement in the procedure GLM.

\section{Results \\ Increasing amounts of calcium chloride fertiliser applied to grassland (Experiment 1)}

Application of calcium chloride did not affect the forage dry matter yield in the first cut of the fertilisation experiment in either year at any of the three sites (Table 2). However, application of chloride increased the forage concentration of $\mathrm{Cl}$ and lowered the DCAD. The difference in DCAD between applications of 70 and $140 \mathrm{~kg} \mathrm{Cl} \mathrm{ha}^{-1}$ was not statistically significant, but a further increase to $210 \mathrm{~kg} \mathrm{Cl} \mathrm{ha}^{-1}$ resulted in a lower DCAD. An increase in potassium supply from a low (53 kg K ha-1) to a 'normal' level (108 kg K ha-1) affected neither the yield nor the concentration of potassium in the forage. The forage potassium concentration and DCAD were considerably higher at the field trial in Stjørdal than at the two other sites, and DCAD decreased from year one to year two, mainly due to a lower concentration of potassium in the forage of year two. There was a significant interaction between fertiliser treatment and year for the forage concentrations of both potassium and chloride. Supply of 108 versus 53 $\mathrm{kg} \mathrm{K}$ per hectare, only increased the concentration of $\mathrm{K}$ in the forage of year two.

Table 2. Experiment 1: Forage dry matter yield, concentrations of mineral dietary cation-anion difference (DCAD) at the first cut of fields dominated by timothy and meadow fescue, fertilised with different amounts of chloride and potassium, and harvested at three locations (Meldal, Stjørdal and Haram) during two years.

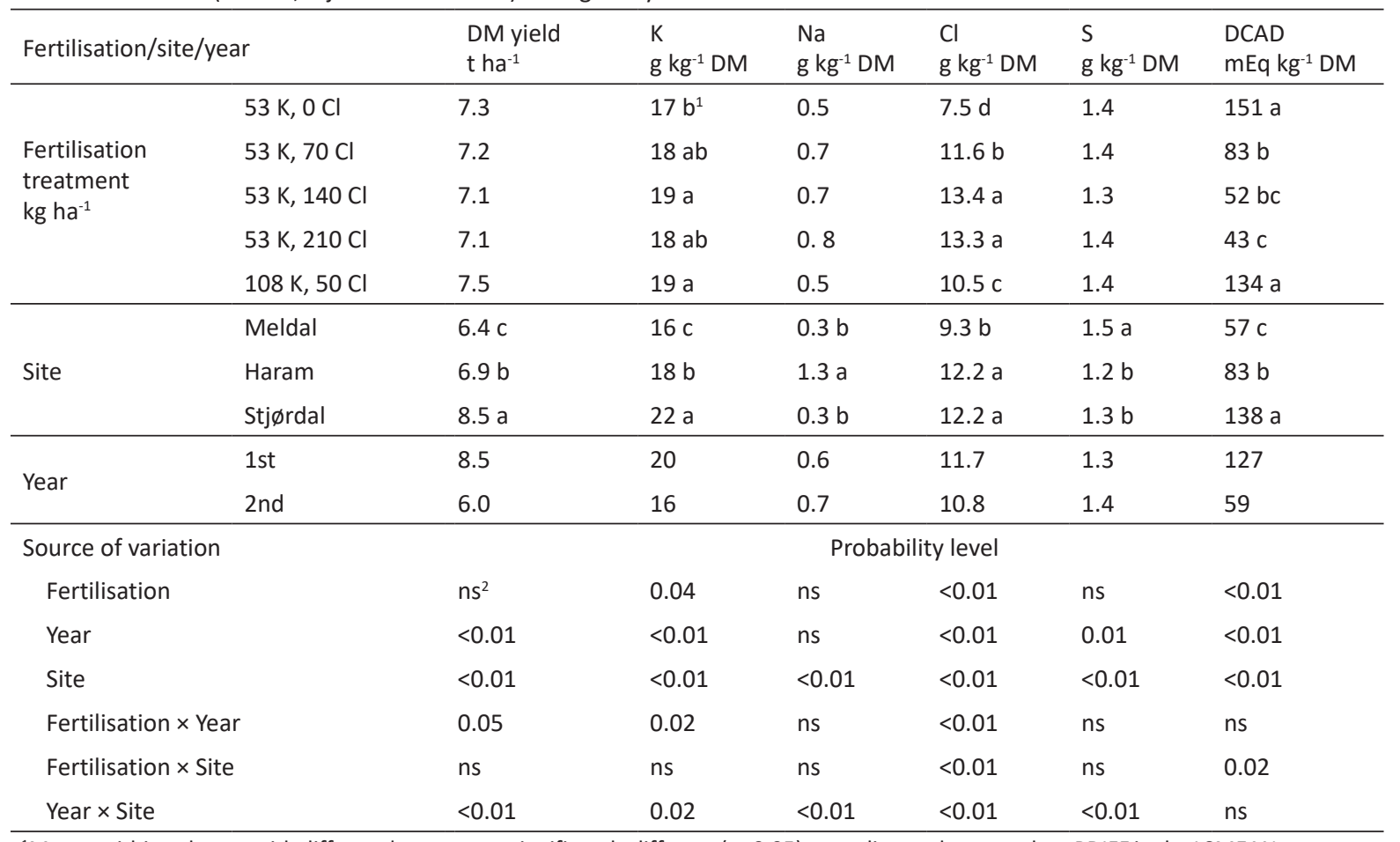

${ }^{1}$ Means within columns with different letters were significantly different ( $\left.p \leq 0.05\right)$ according to the procedure PDIFF in the LSMEAN statement; 2ns: $p>0.05$

There was no significant effect of fertiliser treatment on the concentrations of crude protein, water-soluble carbohydrates, indigestible fibre and energy concentration $\left(\mathrm{NEL}_{20}\right)$. Chloride fertilisation significantly increased the concentration of fibres (NDF), and lowered the dry matter digestibility (DMD), but the differences were quite small, and probably of no practical importance. The average energy concentration was $5.2 \mathrm{MJ} \mathrm{kg}^{-1} \mathrm{DM}_{(\mathrm{NEL}}$ ), the average concentration of crude protein was $110 \mathrm{~g} \mathrm{~kg}^{-1} \mathrm{DM}$ and the average NDF concentration was $616 \mathrm{~g} \mathrm{~kg}^{-1} \mathrm{DM}$. 


\section{AGRICULTURAL AND FOOD SCIENCE}

\section{Chloride applied to grassland in either calcium or magnesium compounds (Experiment 2)}

Forage dry matter yield, DCAD and mineral concentrations are shown in Table 3 for this field trial. The DM yield differed significantly between fertilization treatments. The highest yield was obtained at 'normal' compared to low rates of $\mathrm{K}$ supply, and the lowest yield was in the treatment with low $\mathrm{K}$ and very high $\mathrm{Cl}$ supply rates. It was however, not possible to separate means in the pairwise comparison test (Table 3). At the low level of potassium fertilisation, low and even negative values of DCAD were obtained, so long as $\mathrm{Cl}$ was supplied simultaneously. The concentration of potassium in the plants was very low, but it was significantly higher at the 'normal' level of potassium fertilisation $\left(108 \mathrm{~kg} \mathrm{~K} \mathrm{ha}^{-1}\right)$ than at the low level $\left(53 \mathrm{~kg} \mathrm{~K} \mathrm{ha}^{-1}\right)$. Soil samples taken before the start of the experiment showed concentrations of $40 \mathrm{mg} \mathrm{K}-\mathrm{AL} \mathrm{kg}^{-1}$ and $250 \mathrm{mg} \mathrm{K}-\mathrm{HNO}_{3} \mathrm{~kg}^{-1}$ (Table 1), which are both classified as 'low' values. The forage concentration of sodium was much higher than in the other field experiments (Tables $2-5)$, and higher in the second year ( $\left.4.7 \mathrm{~g} \mathrm{~kg}^{-1} \mathrm{DM}\right)$ than in the first (2.6 $\left.\mathrm{g} \mathrm{kg}^{-1} \mathrm{DM}\right)$. The concentration of $\mathrm{Mg}$ was significantly higher in treatments with $\mathrm{MgCl}_{2}$ as $\mathrm{Cl}$ source than in treatments with $\mathrm{CaCl}_{2}$ as $\mathrm{Cl}$ source, and vice-versa for the concentration of $\mathrm{Ca}$ (Table 3). There was no effect of chloride source on forage DCAD. Fertilisation with $280 \mathrm{~kg} \mathrm{Cl} \mathrm{ha}^{-1}$ did not decrease the DCAD compared to $140 \mathrm{~kg} \mathrm{Cl}$, but the concentration of $\mathrm{Cl}$ was higher. There was no significant interaction between fertilisation treatment and year of experiment, except in the case of $\mathrm{Mg}$ concentration, where the numerical difference in concentration between the two $\mathrm{Cl}$ sources was higher in year 2 than in year 1 (data not presented).

Table 3. Experiment 2: Forage dry matter yield, dietary cation-anion difference (DCAD) and mineral concentrations at the first cut. Effects of calcium chloride, magnesium chloride and potassium fertilisation on leys dominated by timothy and meadow fescue. Average of one field trial at Vigra in two years.

\begin{tabular}{|c|c|c|c|c|c|c|c|c|c|}
\hline \multicolumn{2}{|c|}{$\begin{array}{l}\text { Fertilisation/ } \\
\text { year of experiment }\end{array}$} & $\begin{array}{l}\text { DM yield } \\
\mathrm{t} \mathrm{ha}^{-1}\end{array}$ & $\begin{array}{c}\mathrm{K} \\
\mathrm{g} \mathrm{kg}^{-1} \mathrm{DM}\end{array}$ & $\begin{array}{c}\mathrm{Na} \\
\mathrm{g} \mathrm{kg}^{-1} \mathrm{DM}\end{array}$ & $\begin{array}{c}\mathrm{Cl} \\
\mathrm{g} \mathrm{kg}^{-1} \mathrm{DM}\end{array}$ & $\stackrel{\mathrm{S}}{\mathrm{g} \mathrm{kg}^{-1} \mathrm{DM}}$ & $\begin{array}{c}\text { DCAD } \\
\mathrm{mEq} \mathrm{kg}{ }^{-1} \mathrm{DM}\end{array}$ & $\underset{\mathrm{gg}}{\mathrm{Mg}}$ & $\begin{array}{c}\mathrm{Ca} \\
\mathrm{g} \mathrm{kg}^{-1} \mathrm{DM}\end{array}$ \\
\hline \multirow{5}{*}{$\begin{array}{l}\text { Fertilisation } \\
\text { treatment } \\
\mathrm{kg} \mathrm{ha}^{-1}\end{array}$} & $53 \mathrm{~K}, 0 \mathrm{Cl}$ & 6.2 & $8 b^{3}$ & 3.3 & $6.9 \mathrm{c}$ & $1.1 \mathrm{ab}$ & $89 a$ & $1.3 b$ & $1.9 \mathrm{c}$ \\
\hline & $53 \mathrm{~K},{ }^{1} 140 \mathrm{Cl}$ & 5.9 & $8 b$ & 3.0 & $9.9 \mathrm{~b}$ & $1.0 \mathrm{~b}$ & $-16 b$ & $1.2 b$ & $2.4 b$ \\
\hline & $53 \mathrm{~K},{ }^{2} 140 \mathrm{Cl}$ & 6.1 & $8 \mathrm{~b}$ & 3.7 & $9.9 \mathrm{~b}$ & $1.1 \mathrm{a}$ & $21 \mathrm{~b}$ & $1.6 a$ & $2.1 b c$ \\
\hline & $53 \mathrm{~K},{ }^{1} 280 \mathrm{Cl}$ & 5.5 & $8 b$ & 4.4 & $11.7 \mathrm{a}$ & $1.2 \mathrm{a}$ & $-2 b$ & $1.2 b$ & $3.0 \mathrm{a}$ \\
\hline & $108 \mathrm{~K}, 50 \mathrm{Cl}$ & 7.1 & $11 \mathrm{a}$ & 2.8 & $9.1 b$ & $1.2 \mathrm{a}$ & $88 \mathrm{a}$ & $1.2 \mathrm{~b}$ & $1.9 c$ \\
\hline \multirow{2}{*}{ Year } & $1 s t$ & 5.9 & 9 & 2.6 & 9.0 & 1.1 & 21 & 1.3 & 2.1 \\
\hline & 2nd & 6.4 & 8 & 4.7 & 10.2 & 1.1 & 58 & 1.3 & 2.5 \\
\hline \multicolumn{2}{|c|}{ Source of variation } & \multicolumn{8}{|c|}{ Probability level } \\
\hline \multicolumn{2}{|c|}{ Fertilisation } & 0.05 & 0.01 & $\mathrm{~ns}^{4}$ & $<0.01$ & 0.02 & $<0.01$ & 0.01 & $<0.01$ \\
\hline \multicolumn{2}{|l|}{ Year } & ns & ns & $<0.01$ & 0.01 & ns & 0.01 & ns & 0.02 \\
\hline \multicolumn{2}{|c|}{ Fert. $\times$ Year. } & ns & ns & ns & ns & ns & ns & 0.03 & ns \\
\hline
\end{tabular}

${ }^{1}$ calcium chloride, ${ }^{2}$ magnesium chloride, ${ }^{3}$ means within columns with different letters were significantly different ( $p \leq 0.05$ ) according to the procedure PDIFF in the LSMEAN statement, ${ }^{4} n s: p>0.05$

\section{Chloride applied either at spring fertilisation or two weeks later (Experiment 3)}

The timing of $\mathrm{Cl}$ application was not important for the effects on $\mathrm{Cl}$ concentration and DCAD in grasses at the first cut (Table 4). Both treatments led to a $45 \%$ increase in tissue $\mathrm{Cl}$ content compared to the control treatment with no $\mathrm{Cl}$. At Stjørdal, where the soil concentration of $\mathrm{K}^{-\mathrm{HNO}_{3}}$ was $1100 \mathrm{mg} \mathrm{kg}^{-1}$, the DCAD and the concentration of potassium in the plants were considerably higher than at Vigra, where the soil concentration of $\mathrm{K}-\mathrm{HNO}_{3}$ was only $300 \mathrm{mg} \mathrm{kg}^{-1}$. 


\section{AGRICULTURAL AND FOOD SCIENCE}

L. Nesheim et al. (2020) 29: 18-28

Table 4. Experiment 3: Mineral concentrations and dietary cation-anion difference (DCAD) at the first cut. Effects of calcium chloride applied at different times in spring to leys dominated by timothy and meadow fescue. Two field trials in one year.

\begin{tabular}{|c|c|c|c|c|c|c|}
\hline & $\begin{array}{l}\text { Chloride } \\
\text { fertilisation }\end{array}$ & $\begin{array}{c}\mathrm{K} \\
\mathrm{g} \mathrm{kg}^{-1} \mathrm{DM} \\
\end{array}$ & $\begin{array}{c}\mathrm{Na} \\
\mathrm{g} \mathrm{kg}^{-1} \mathrm{DM}\end{array}$ & $\begin{array}{c}\mathrm{Cl} \\
\mathrm{g} \mathrm{kg}^{-1} \mathrm{DM}\end{array}$ & $\begin{array}{c}\mathrm{S} \\
\mathrm{g} \mathrm{kg}^{-1} \mathrm{DM}\end{array}$ & $\begin{array}{c}\text { DCAD } \\
\mathrm{mEq} \mathrm{kg}^{-1} \mathrm{DM}\end{array}$ \\
\hline \multirow{3}{*}{ Cl-fertilisation } & $0 \mathrm{Cl}$ & 19 & 0.9 & $9.9 b^{1}$ & $1.5 \mathrm{a}$ & $151 \mathrm{a}$ \\
\hline & $140 \mathrm{~kg} \mathrm{Cl} \mathrm{ha}^{-1}$ (spring) & 21 & 0.7 & $14.9 \mathrm{a}$ & $1.2 \mathrm{~b}$ & $62 \mathrm{~b}$ \\
\hline & $140 \mathrm{~kg} \mathrm{Cl} \mathrm{ha}^{-1}$ (14 days later) & 19 & 1.5 & $14.7 \mathrm{a}$ & $1.3 \mathrm{ab}$ & $42 \mathrm{~b}$ \\
\hline \multirow{2}{*}{ Site } & Stjørdal & 22 & 0.1 & 13.0 & 1.1 & 126 \\
\hline & Vigra & 17 & 1.9 & 13.4 & 1.6 & 44 \\
\hline \multicolumn{2}{|c|}{ Source of variation } & \multicolumn{5}{|c|}{ Probability level } \\
\hline \multicolumn{2}{|c|}{ Chloride fertilisation } & $n s^{2}$ & ns & $<0.01$ & 0.04 & $<0.01$ \\
\hline \multicolumn{2}{|l|}{ Site } & $<0.01$ & 0.01 & ns & $<0.01$ & $<0.01$ \\
\hline \multicolumn{2}{|c|}{ Chloride fertilisation $x$ Site } & ns & ns & ns & ns & ns \\
\hline
\end{tabular}

${ }^{1}$ Means within columns with different letters were significantly different $(p \leq 0.05)$ according to the procedure PDIFF in the LSMEAN statement, ${ }^{2} n s: p>0.05$

\section{DCAD in different grass species (Experiment 4)}

Without chloride application, the DCAD varied from $200 \mathrm{mEq} \mathrm{kg}{ }^{-1} \mathrm{DM}$ in reed canary grass to $388 \mathrm{mEq} \mathrm{kg}^{-1}$ DM in cocksfoot, averaged over two sites (Haram and Stjørdal), and for the first year (Table 5). When chloride

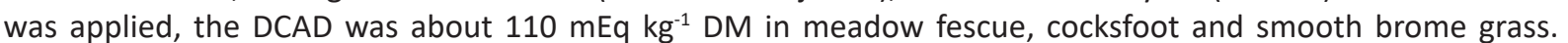

Table 5. Experiment 4: Forage dry matter yield, mineral concentrations and Dietary cation-anion difference (DCAD) at the first cut in the first ley year according to chloride fertilisation and species (average of two sites) and according to site.

\begin{tabular}{|c|c|c|c|c|c|c|c|c|}
\hline $\begin{array}{l}\text { Cl-fertilisation/ } \\
\text { Site }\end{array}$ & Species & $\begin{array}{l}\text { DM yield } \\
\mathrm{tha}^{-1}\end{array}$ & $\begin{array}{c}\mathrm{K} \\
\mathrm{g} \mathrm{kg}^{-1} \mathrm{DM}\end{array}$ & $\begin{array}{c}\mathrm{Na} \\
\mathrm{g} \mathrm{kg}^{-1} \mathrm{DM}\end{array}$ & $\begin{array}{c}\mathrm{Cl} \\
\mathrm{g} \mathrm{kg}^{-1} \mathrm{DM}\end{array}$ & $\begin{array}{c}\mathrm{S} \\
\mathrm{g} \mathrm{kg}^{-1} \mathrm{DM}\end{array}$ & $\begin{array}{c}\text { Ash } \\
\mathrm{g} \mathrm{kg}^{-1} \mathrm{DM}\end{array}$ & $\begin{array}{l}\text { DCAD } \\
\mathrm{mEq} \mathrm{kg}^{-1} \\
\mathrm{DM}\end{array}$ \\
\hline \multirow[t]{7}{*}{$\mathrm{No} C \mathrm{l}$} & Timothy & $7.4 b c^{1}$ & $19 \mathrm{~cd}$ & $0.1 \mathrm{~cd}$ & $5.7 \mathrm{gh}$ & $1.1 \mathrm{c}$ & $56 \mathrm{~cd}$ & $250 \mathrm{bc}$ \\
\hline & Mead. fescue & $7.2 \mathrm{bc}$ & $22 c$ & $0.2 \mathrm{~cd}$ & 9.3 ef & $1.4 a b$ & $63 \mathrm{bc}$ & $211 c$ \\
\hline & Cocksfoot & $6.5 c$ & $24 \mathrm{bc}$ & $0.6 \mathrm{bcd}$ & $6.1 \mathrm{gh}$ & $1.4 \mathrm{ab}$ & $63 \mathrm{bc}$ & 388 a \\
\hline & S. brome grass & $9.0 \mathrm{a}$ & $15 d$ & $0.1 \mathrm{~cd}$ & $4.5 \mathrm{~h}$ & $0.8 \mathrm{~d}$ & $39 \mathrm{f}$ & $205 c$ \\
\hline & Reed c. grass & $7.1 \mathrm{c}$ & $18 \mathrm{~d}$ & $0.2 \mathrm{~cd}$ & $6.4 \mathrm{fgh}$ & $1.3 \mathrm{~b}$ & 50 de & $200 c$ \\
\hline & P. ryegrass & $6.5 \mathrm{c}$ & $22 c$ & $1.2 \mathrm{~b}$ & $7.4 \mathrm{fgh}$ & $1.5 \mathrm{ab}$ & $56 \mathrm{~cd}$ & $318 a b$ \\
\hline & Festulolium & $7.1 \mathrm{bc}$ & $24 \mathrm{bc}$ & $0.8 \mathrm{bcd}$ & $7.6 \mathrm{fg}$ & $1.6 \mathrm{a}$ & $62 b c$ & $323 a b$ \\
\hline \multirow[t]{7}{*}{$140 \mathrm{~kg} \mathrm{Cl} \mathrm{ha}^{-1}$} & Timothy & $7.1 \mathrm{bc}$ & $21 \mathrm{~cd}$ & $0.1 \mathrm{~cd}$ & $13.7 \mathrm{~cd}$ & $1.1 \mathrm{c}$ & $63 \mathrm{bc}$ & 90 de \\
\hline & Mead. fescue & $7.7 \mathrm{abc}$ & $24 \mathrm{bc}$ & $0.1 \mathrm{~cd}$ & $15.4 \mathrm{c}$ & $1.4 \mathrm{~b}$ & $64 \mathrm{bc}$ & $108 \mathrm{de}$ \\
\hline & Cocksfoot & $6.0 c$ & $29 \mathrm{a}$ & $1.1 \mathrm{bc}$ & $20.8 a b$ & $1.3 \mathrm{~b}$ & $74 \mathrm{a}$ & $117 d$ \\
\hline & S. brome grass & $8.5 a b$ & $18 \mathrm{~cd}$ & $0.1 \mathrm{~d}$ & $10.9 \mathrm{de}$ & $0.9 \mathrm{~cd}$ & 46 ef & $108 \mathrm{de}$ \\
\hline & Reed c. grass & $7.0 \mathrm{c}$ & $20 \mathrm{~cd}$ & $0.4 \mathrm{~cd}$ & $14.3 \mathrm{c}$ & $1.3 \mathrm{bc}$ & $60 \mathrm{bc}$ & 30 e \\
\hline & P. ryegrass & $6.6 c$ & $26 \mathrm{~b}$ & $2.1 \mathrm{a}$ & $21.4 \mathrm{a}$ & $1.4 \mathrm{ab}$ & $68 a b$ & 58 e \\
\hline & Festulolium & $7.4 \mathrm{bc}$ & $25 \mathrm{bc}$ & $0.6 \mathrm{bcd}$ & $18.2 \mathrm{bc}$ & $1.4 \mathrm{~b}$ & $65 \mathrm{bc}$ & 66 de \\
\hline \multicolumn{2}{|l|}{ Haram } & 7.3 & 21 & 0.8 & 11.2 & 1.3 & 56 & 178 \\
\hline \multicolumn{2}{|l|}{ Stjørdal } & 7.1 & 22 & 0.3 & 11.8 & 1.2 & 62 & 175 \\
\hline \multicolumn{2}{|c|}{ Source of variation } & \multicolumn{7}{|c|}{ Probability level } \\
\hline \multicolumn{2}{|c|}{ Chloride fertilisation } & $n s^{2}$ & $<0.01$ & ns & $<0.01$ & ns & $<0.01$ & $<0.01$ \\
\hline \multicolumn{2}{|l|}{ Species } & $<0.01$ & $<0.01$ & $<0.01$ & $<0.01$ & $<0.01$ & $<0.01$ & $<0.01$ \\
\hline \multicolumn{2}{|l|}{ Site } & ns & ns & ns & $<0.01$ & ns & ns & 0.01 \\
\hline \multicolumn{2}{|c|}{ Chloride fert. x Species } & ns & ns & $<0.01$ & ns & ns & 0.01 & ns \\
\hline \multicolumn{2}{|c|}{ Chloride fert. $x$ Site } & ns & ns & ns & ns & ns & ns & ns \\
\hline
\end{tabular}

${ }^{1}$ Means within columns with different letters were significantly different $(p \leq 0.05)$ according to the procedure PDIFF in the LSMEAN statement; ${ }^{2}$ ns: $p>0.05$ 


\section{AGRICULTURAL AND FOOD SCIENCE}

L. Nesheim et al. (2020) 29: 18-28

The lowest values were found in perennial ryegrass (58 $\left.\mathrm{mEq} \mathrm{kg}^{-1} \mathrm{DM}\right)$ and reed canary grass (30 $\left.\mathrm{mEq} \mathrm{kg}{ }^{-1} \mathrm{DM}\right)$. Averaged over all species, chloride fertilisation reduced DCAD from 271 to $86 \mathrm{mEq} \mathrm{kg}^{-1} \mathrm{DM}$, and increased the concentrations of chloride and potassium. For the concentrations of chloride and DCAD, there were significant interactions between $\mathrm{Cl}$ fertilisation and species. The DCAD after $\mathrm{Cl}$ fertilisation was considerably more reduced in reed canary grass, perennial ryegrass and festulolium than in meadow fescue and smooth brome grass, and the concentrations of chloride increased more in cocksfoot and perennial ryegrass than in meadow fescue. There were significant differences between species in all mineral concentrations and DCAD, and also in yield. The highest yield was produced by smooth brome grass, and the lowest by cocksfoot and perennial ryegrass. This may simply be because the former species was harvested one week later than the latter two. The herbage ash concentration increased from $55 \mathrm{~g} \mathrm{~kg}^{-1} \mathrm{DM}$ on plots with no chloride fertilisation to $61 \mathrm{~g} \mathrm{~kg}^{-1} \mathrm{DM}$ on plots fertilised with chloride.

Averaged over all species, the total uptake of $\mathrm{K}$ was $147 \mathrm{~kg} \mathrm{ha}^{-1}$ when no $\mathrm{Cl}$ fertiliser was applied, and increased by $18 \mathrm{~kg} \mathrm{ha}^{-1}$ with $\mathrm{Cl}$ fertiliser. Smooth brome grass and reed canary grass had the lowest $\mathrm{K}$ uptake, approximately $130 \mathrm{~kg} \mathrm{ha}^{-1}$, and festulolium had the highest with $170 \mathrm{~kg} \mathrm{ha}^{-1}$.

The uptake of $\mathrm{Cl}$ on plots without $\mathrm{Cl}$-fertiliser varied from 40 to $67 \mathrm{~kg} \mathrm{ha}^{-1}$. The effect of $\mathrm{Cl}$ fertiliser on the uptake of $\mathrm{Cl}$ differed markedly between species. For timothy, meadow fescue, smooth brome grass and reed canary grass the increased $\mathrm{Cl}$ uptake with $\mathrm{Cl}$ fertilisation was about $54 \mathrm{~kg} \mathrm{ha}^{-1}$, whereas for cocksfoot, perennial ryegrass and festulolium the corresponding increase was approximately $86 \mathrm{~kg} \mathrm{ha}^{-1}$.

In the second year of ley (data not presented), the mineral concentrations were only analysed in the treatment with $140 \mathrm{~kg} \mathrm{Cl} \mathrm{ha}^{-1}$. The differences in DCAD between species were similar to those found in the first year, but they were not significant. The average value of DCAD was somewhat higher in the first year ( $\left.82 \mathrm{mEq} \mathrm{kg}^{-1} \mathrm{DM}\right)$ than in the second year (49 $\left.\mathrm{mEq} \mathrm{kg}^{-1} \mathrm{DM}\right)$.

Chloride fertilisation influenced both the concentration of NDF and the digestibility of organic matter (Table 6). The concentration of crude protein was quite low in all species. The recommended energy concentration for non-lactating cows more than two weeks prior to calving is 4.8-5.1 $\mathrm{MJ} \mathrm{NEL}_{20} \mathrm{~kg}^{-1} \mathrm{DM}$ (TINE Rådgiving 2014).

Table 6. Experiment 4: Forage concentrations of crude protein, fibre (NDF and iNDF) water soluble carbohydrates (WSC) and energy $\left(\mathrm{NEL}_{20}\right)$, along with digestibility of dry matter (DMD) in the first cut of seven grass species grown at two sites in one year.

\begin{tabular}{|c|c|c|c|c|c|c|c|}
\hline & & $\begin{array}{l}\text { Crude prot. } \\
\mathrm{g} \mathrm{kg}^{-1} \mathrm{DM}\end{array}$ & $\begin{array}{c}\text { NDF } \\
\mathrm{g} \mathrm{kg}^{-1} \mathrm{DM}\end{array}$ & $\begin{array}{c}\text { iNDF } \\
\mathrm{g} \mathrm{kg}^{-1} \mathrm{NDF}\end{array}$ & $\begin{array}{c}\text { WSC } \\
\mathrm{g} \mathrm{kg}^{-1} \mathrm{DM}\end{array}$ & $\begin{array}{c}\text { DMD } \\
\%\end{array}$ & $\begin{array}{l}\text { NEL20 } \\
\text { MJ kg-1 }^{-1}\end{array}$ \\
\hline \multirow{7}{*}{ Species } & Timothy & $92 a^{1}$ & $587 \mathrm{ab}$ & 198 bc & $106 \mathrm{~d}$ & $65 \mathrm{bc}$ & $5.2 \mathrm{bc}$ \\
\hline & Mead. fescue & $98 \mathrm{a}$ & 595 a & $177 \mathrm{~cd}$ & $129 \mathrm{~cd}$ & $66 \mathrm{~b}$ & $5.3 \mathrm{~b}$ \\
\hline & Cocksfoot & $88 a$ & 599 a & $209 \mathrm{~b}$ & $119 \mathrm{~cd}$ & $64 \mathrm{bc}$ & $5.1 \mathrm{bc}$ \\
\hline & S. brome grass & $68 \mathrm{~b}$ & $563 \mathrm{bc}$ & $248 a$ & 215 a & $64 \mathrm{bc}$ & $5.1 \mathrm{bc}$ \\
\hline & Reed c. grass & $87 a$ & $608 \mathrm{a}$ & $261 \mathrm{a}$ & $111 \mathrm{~cd}$ & $61 c$ & $4.9 \mathrm{c}$ \\
\hline & P. ryegrass & $90 \mathrm{a}$ & $544 \mathrm{c}$ & $157 d$ & $183 \mathrm{~b}$ & $71 \mathrm{a}$ & $5.8 \mathrm{a}$ \\
\hline & Festulolium & $94 \mathrm{a}$ & 595 a & $173 \mathrm{~cd}$ & $134 \mathrm{c}$ & $66 \mathrm{~b}$ & $5.3 \mathrm{~b}$ \\
\hline \multirow{2}{*}{ Cl-fertilisation } & $0 \mathrm{Cl}$ & 87 & 572 & 198 & 151 & 66 & 5.3 \\
\hline & 140 kg Cl ha-1 & 89 & 597 & 209 & 134 & 64 & 5.2 \\
\hline \multirow{2}{*}{ Site } & Haram & 84 & 617 & 228 & 121 & 62 & 4.9 \\
\hline & Stjørdal & 92 & 551 & 178 & 164 & 68 & 5.5 \\
\hline \multicolumn{2}{|c|}{ Source of variation } & \multicolumn{6}{|c|}{ Probability level } \\
\hline \multicolumn{2}{|c|}{ - Chloride fertilisation } & $\mathrm{ns}^{2}$ & 0.01 & ns & ns & 0.04 & ns \\
\hline \multicolumn{2}{|l|}{ - Species } & $<0.01$ & 0.01 & $<0.01$ & $<0.01$ & $<0.01$ & $<0.01$ \\
\hline \multicolumn{2}{|l|}{ - Site } & $<0.01$ & $<0.01$ & $<0.01$ & $<0.01$ & $<0.01$ & $<0.01$ \\
\hline \multicolumn{2}{|c|}{ - Chloride fert. x Species } & ns & ns & ns & ns & ns & ns \\
\hline \multicolumn{2}{|c|}{ - Chloride fert. $x$ Site } & ns & ns & ns & ns & ns & ns \\
\hline
\end{tabular}




\section{AGRICULTURAL AND FOOD SCIENCE}

L. Nesheim et al. (2020) 29: 18-28

In reed canary grass, which had the lowest DCAD (Table 6), the energy concentration was 4.7 and $5.0 \mathrm{MJ} \mathrm{NEL}_{20}$ $\mathrm{kg}^{-1}$ at the two sites, respectively, which was almost within the recommended range. In the cases of timothy and cocksfoot, the energy concentration was within the recommended values for dry cows prior to calving. Perennial ryegrass had a DCAD of $58 \mathrm{mEq} \mathrm{kg}^{-1} \mathrm{DM}$ and an energy concentration of $5.8 \mathrm{MJ} \mathrm{NEL}_{20} \mathrm{~kg}^{-1}$, which was higher than recommended. The $\mathrm{NEL}_{20}$ of meadow fescue and festulolium was also higher than the recommended values, particularly when no chloride was applied. There was no significant interaction between chloride fertilisation and grass species.

\section{Discussion}

The present study confirmed earlier findings (Pehrson et al. 1999, Pelletier et al. 2007, Tremblay et al. 2013) that it is possible to increase the concentration of chloride in perennial grasses, and thus to reduce the DCAD in grassbased forages, even to negative values, by chloride fertilisation.

Tremblay et al. (2013) found that timothy-based swards accumulated increasing amounts of chloride up to supply rates of $144 \mathrm{~kg} \mathrm{Cl} \mathrm{ha}^{-1}$ in spring growth. In the present study, there were differences between sites and experiments in response saturation rates. Considerable increases in tissues concentrations, with no parallel yield reductions, were recorded at supply rates of up to at least $188 \mathrm{~kg} \mathrm{Cl} \mathrm{ha}^{-1}$ (140 kg basic dose $+48 \mathrm{~kg}_{\text {from Fullgjødsel }}{ }^{\circ}$ 22-3-10). Even the highest application rates tested in the present study, of 258 and $280 \mathrm{~kg} \mathrm{Cl} \mathrm{ha}^{-1}$ in experiment 1 and 2, respectively, did not result in tissue concentrations approaching the suggested toxic level for plants of 30 $\mathrm{g} \mathrm{kg}^{-1}$ DM (Whitehead 2000).

Irrespective of location and soil related background concentrations of potassium, Cl-fertilisation effectively reduced the DCAD in the harvested yield. Even at the Stjørdal site on clay loam, a DCAD as low as 38 was recorded in treatments with low $\mathrm{K}$ supply and application of $140-210 \mathrm{~kg} \mathrm{Cl} \mathrm{ha}^{-1}$ (data not shown) This is, however, still well above the recommended value of around $-50 \mathrm{mEq} \mathrm{kg}^{-1} \mathrm{DM}$ (Pelletier et al. 2007, Goff 2014). Negative forage DCAD was obtained in Experiment 2 on sandy soils at Vigra with a content of acid soluble potassium as low as 25 mg per $100 \mathrm{~g}$ soil. Regarding risks of dramatic yield losses caused by low K supply on soils poor in plant available $\mathrm{K}$, they did not seem to be very high. There were, however, differences in yield according to K supply at Vigra, and we cannot conclude that risks are low in general.

In our second hypothesis we postulated that $\mathrm{MgCl}_{2}$ and $\mathrm{CaCl}_{2}$ were equally efficient as $\mathrm{Cl}$-sources for grasses and that the former would contribute to a higher concentration of $\mathrm{Mg}$ in the forage. It was of interest to test this because a low dietary Mg supply, and resulting cow hypomagnesemia, may imply a higher risk for milk fever (Goff et al. 2014). Further, the commercially available magnesium salt in Norway is presently not granulated to be appropriate for spreading with a spinning disk distributor. The commercially available $\mathrm{CaCl}_{2}$ product is granulated, but its solubility in water is lower than that of the $\mathrm{MgCl}_{2}$ product. Based on the experiment conducted at Vigra, there were no differences between the two $\mathrm{Cl}$-sources in terms of plant availability of the chloride. The $\mathrm{Mg}$ and Ca concentrations were affected by fertilizer type, but even the highest levels ( 1.6 and $3.0 \mathrm{~g} \mathrm{~kg}^{-1} \mathrm{DM}$, respectively) were within the lower range of what has been found in previous surveys and investigations of forage in Norway (Johansen et al. 2003, Fystro and Bakken 2005). There is thus no basis for recommending farmers to use $\mathrm{MgCl}_{2}$ rather than $\mathrm{CaCl}_{2}$.

Our third hypothesis regarded the timing of $\mathrm{Cl}$-supply, and suggested that more of the $\mathrm{Cl}$ might be recovered in the harvested yield when the application was postponed a couple weeks after the spring NPK fertilisation. There appeared, however, to be no significant effect of timing on either the concentration of Cl or the DCAD in the first cut at the two sites Stjørdal and Vigra. The precipitation in spring in the year of study was rather high (169 and $195 \mathrm{~mm}$, respectively, from first fertilization until harvest), and the possibility of leakage losses of early applied doses was thus investigated and considered to be negligible. The normal precipitation in May-June at both sites is $120 \mathrm{~mm}$ (The Norwegian Meteorological Institute).

The next hypothesis we tested in the present study was that $\mathrm{Cl}$ fertilization might be a more efficient means overall of controlling DCAD in forage compared to growing specific species with low risk of excessive DCAD. Average over all species and sites, chloride fertilization reduced the DCAD from 271 to $86 \mathrm{mEq} \mathrm{kg}^{-1} \mathrm{DM}$, and the range for species when no $\mathrm{Cl}$ was applied, was from $388 \mathrm{mEq} \mathrm{kg}^{-1} \mathrm{DM}$ in cocksfoot to $200 \mathrm{mEq} \mathrm{kg}{ }^{-1} \mathrm{DM}$ in reed canary grass. 


\section{AGRICULTURAL AND FOOD SCIENCE}

L. Nesheim et al. (2020) 29: 18-28

The difference in numeric terms was thus about the same for both comparisons, but regarding the range for species in the treatment without $\mathrm{Cl}$-fertiliser, all attained a DCAD far above that which has been recommended for dry cows before calving (Pelletier et al. 2007, Goff 2014). It was first after having applied extra Cl, that DCAD was found to be, at least in some species, well below $100 \mathrm{mEq} \mathrm{kg}^{-1} \mathrm{DM}$, with $30 \mathrm{mEq}$ in reed canary grass as the lowest. This species was not that which accumulated most $\mathrm{Cl}$, and its low rank with regard to DCAD was to a large extent caused by its low affinity for $\mathrm{K}$. The highly ranked cocksfoot contained in fact less $\mathrm{Cl}$, but far more $\mathrm{K}$ in its tissues.

In the Canadian studies by Tremblay et al. $(2006,2013)$, timothy appeared to be a species well-suited for the production of dry cow forage. It was also among the best ones in the present study, both because of a rather low concentration of $\mathrm{K}$ and a high concentration of $\mathrm{Cl}$ in its tissues. Our findings that reed canary grass had the necessary characteristics and that cocksfoot was among the species with highest DCAD, were also in agreement with the results reported by Tremblay et al. (2006, 2013).

Our conclusion to the question of whether growing specific species is an efficient option for producing the recommended forage for dry cows prior to calving, is that it may be of additional benefit to the practice of extra $\mathrm{Cl}$ fertilization, but that it on its own has little chance of achieving the aim of a near zero or negative DCAD.

Forages for dry cows should preferably also be of low digestibility and low energy concentration (TINE Rådgiving 2014), both of which are obtained by harvesting at late phenological stages. In this regard, the target was reached in the present experiment(s), since, as well as lowering DCAD, Cl-fertilisation seemed also to contribute to reduced digestibility and increased NDF content. This is in agreement with the findings of Pelletier et al. (2008), but our study did not contribute further to an explanation of these relationships. Pelletier et al. (2008) suggested that high $\mathrm{Cl}$ concentration might be associated with increased cell expansion and plant growth, which in turn may lead to increased deposition of fibre. In our study there was no sign of any positive growth response to extra $\mathrm{Cl}$ application.

\section{Conclusion}

Fertilisation with $70-210 \mathrm{~kg} \mathrm{Cl}$ per hectare in combination with low rates of potassium supply appeared to be an appropriate method for reducing DCAD in forages to a level suitable for feeding dry cows prior to calving. The ideal negative DCAD was only obtained on a soil which was very low in plant available potassium. Although there were consistent differences between grass species with regard to how much chloride they accumulated, both with and without extra $\mathrm{Cl}$ supply, the use of only certain species does not seem to be an efficient strategy for the production of dry cow forages.

\section{Acknowledgements}

This work was funded by the Regional Research Fund in Central and Western Norway, the County Governors in Central and Western Norway, TINE, Yara and The Norwegian Agricultural Purchasing and Marketing Co-operation (FK Fôrutvikling). We thank Ragnhild Borchsenius, Norwegian Agricultural Extension Service Sør-Trøndelag, for technical assistance with the field trial at Meldal, and Hugh Riley, NIBIO, for checking the English language.

\section{References}

Egnér, H., Riehm, H. \& Domingo, W.R. 1960. Untersuchungen über die chemische Boden-Analyse als Grundlage für die Beurteilung des Nährstoffzustandes der Boden. Kungliga Lantbrukshögskolans Annaler 26: 199-215.

Ender, F., Dishington, I.W. \& Helgebostad, A. 1971. Calcium balance studies in dairy cows under experimental induction and prevention of Hypocalcaemic paresis puerperalis. The solution of the aetiology and the prevention of milk fever by dietary means. Zeitschrift für Tierphysiologie Tierernährung und Futtermittelkunde 28: 233-256.https://doi.org/10.1111/j.1439-0396.1971. tb01573.x

Foseide Henriksen, B. 2003. Effekt av økologisk og konvensjonelt dyrka grovfôr på førebygging av mjølkefeber. Grønn Kunnskap 7: 157-166. (in Norwegian).

Fystro, G. \& Bakken, A.K. 2005. Soil reaction, yields and herbage element content as affected by lime applied on established leys in a multi-site field trial. Journal of Agricultural Science 143: 407-420. https://doi.org/10.1017/S0021859605005605

Fystro, G. \& Lunnan, T. 2006. Analysar av grovfôrkvalitet på NIRS (Analyses of forage quality by NIRS). In: Kristoffersen,A. $\varnothing$. (ed.). Proceedings of the Plantem $\varnothing$ tet $\emptyset$ stlandet 2006. Bioforsk FOKUS 1: 180-182. (in Norwegian).

Goff, J.P. 2014. Calcium and magnesium disorders. Veterinary Clinics of North America: Food Animal Practice 30: $359-381$. https://doi.org/10.1016/j.cvfa.2014.04.003 


\section{AGRICULTURAL AND FOOD SCIENCE}

L. Nesheim et al. (2020) 29: 18-28

Hove, K. 1998. Kation-anion balansen i fôr til drøvtyggere. Virkning på syre-base-balansen i kroppen og på forebygging av melkefeber. I: Husdyrfors $\varnothing$ ksm $\varnothing$ tet 1998. p. 653-657. Forskningsparken i Ås. (in Norwegian).

Johansen, A., Ljøkjel, K. \& Nordang, L. 2003. Grovfôret åleine kan sjeldan gi ei god nok mineralforsyning til drøvtyggarar. Grønn kunnskap 7: 103-111. (in Norwegian).

Lunnan, T., Øgaard, A.F. \& Krogstad, T. 2017. Potassium fertilization of timothy-based cut grassland-Effects on herbage yield, mineral composition and critical K concentration on soils with different K status. Grass and Forage Science 73: 500-509. https://doi. org/10.1111/gfs.12341

Martín-Tereso, J. \& Martens, H. 2014. Calcium and magnesium physiology and nutrition in relation to the prevention of milk fever and tetany (dietary management of macrominerals in preventing disease). Veterinary Clinics of North America: Food Animal Practice 30: 643-670. https://doi.org/10.1016/j.cvfa.2014.07.007

Pehrson, B., Svensson, C., Gruvaeus, I. \& Virkki, M. 1999. The influence of acidic diets on the acid-base balance of dry cows and the effect of fertilization on the mineral concentration of grass. Journal of Dairy Science 82: 1310-1316. https://doi.org/10.3168/ jds.S0022-0302(99)75354-3

Pelletier S., Bélanger, G., Tremblay, G.F., Seguin, P., Drapeau, R. \& Allard, G. 2007. Dietary cation-anion difference of Timothy (Phleum pratense L.) as influenced by application of chloride and nitrogen fertiliser. Grass and Forage Science 62: 66-77. https:// doi.org/10.1111/j.1365-2494.2007.00565.x

Pelletier S., Tremblay, G.F., Bélanger, G., Chantigny, M.H., Seguin, P., Drapeau, R. \& Allard, G. 2008. Nutritive value of timothy fertilised with chloride or chloride-containing liquid swine manure. Journal of Dairy Science 91: 713-721. https://doi.org/10.3168/ jds.2007-0429

Sundst $\varnothing$ I, F. \& Ekern, A. 1992. Det nye energivurderingssystemet for drøvtyggere (FEm-systemet) og nye energinormer. FAGINFO 13: $546-552$. (in Norwegian).

TINE 2015. https://medlem.tine.no/fagprat/driftsledelse/f\%C3\%B4renheten-erstattes-med-megajoule

TINE Rådgiving 2014. Sinkufôring - grunnlaget for neste laktasjon (Dry cow feeding - preparation for next lactation). https://medlem. tine.no/aktuelt/nyheter/fagnytt/_attachment/352534?_ts...true. Accessed September 2018. 16 p. (in Norwegian).

Tremblay, G.F., Brassard, H., Bélanger, G., Seguin, P., Drapeau, R. \& Brégard, A. 2006. Dietary cation anion difference of five coolseason grasses. Agronomy Journal 98: 339-348. https://doi.org/10.2134/agronj2005.0161

Tremblay, G., Bélanger, G., Pelletier, S., Lajeunesse, J. \& Pageau, D. 2013. Dietary cation-anion difference of forage species after chloride fertilization. Agronomy Journal 105: 455-462. https://doi.org/10.2134/agronj2012.0355

Whitehead, D.C. 2000. Nutrient elements in grassland. Soil-plant-animal relationships. CABI Publishing, Wallingford, Oxon, UK. 369 p. https://doi.org/10.1079/9780851994376.0000 